\title{
The Root Analysis and the Impact on China of Sub-loan Crisis
}

\author{
Lei Zhang \\ Department of Accounting, Shandong Economic University \\ Jinan 250014, China \\ E-mail: zhangleilei23@163.com \\ Yuanyuan $\mathrm{Yu}$ \\ Department of Accounting, Shandong Economic University \\ Jinan 250014, China \\ E-mail: starfishyyy@126.com
}

\begin{abstract}
From 2007, a subprime storm began to blows from the US, and sweep across the whole world with a rapid speed. It makes the world economic growth slow -down, even Iceland and a fraction of the world's countries fall into bankrupt. Behind this, the dollar hegemony of which the United States has been proud is exactly the main reason. Actually, the appreciation of RMB and the interest rates raised by the U.S. Federal Reserve have triggered the subprime mortgage crisis. Although the direct impact on China is not extremely great, the indirect influence can't be underestimated. Face to the crisis, China should learn this lesson from it, control the real estate bubble, expand domestic demand and reduce the gap between rich and poor in order to realize the economy transformation.
\end{abstract}

Keywords: Sub-loan Crisis, Dollar Hegemony, Expand Domestic Demand

February 13, 2007, the United States the risk of mortgage loans began to surface, and soon evolved into a so-called "once-in" sub-loan crisis. The two largest U.S.A mortgage finance institutions - Fannie Mae and Freddie Mac, as the loans serious shrunk, liabilities rose rapidly, by the U.S.A government to take over; the fifth-largest U.S. A investment bank Bear Stearns low-cost easy to master; the fourth largest investment Lehman Brothers filed for bankruptcy protection; third-largest investment bank Merrill Lynch \& Co. was acquired by Bank of America; Goldman Sachs and Morgan Stanley transformed into bank holding companies, the top five investment banks dropped across the board. The world's largest insurance agency, American International Group (AIG) are also in a precarious, the United States government has an emergency to the American International Group, 85 billion U.S.A dollars to provide bridging loans. In subprime mortgage crisis effect of the more obvious, we try to sub-loan crisis by the root of the matter, and explore this by many people since the last century known as the 30's "Great Depression" the most serious financial crisis with the revelation to be able to draw lessons from them, clarifying the continued reform and opening up of China's financial industry development

\section{The root of sub- loan crisis}

\subsection{The ultimate root of sub-loan crisis}

About the root of sub-loan crisis, domestic and foreign scholars have done a full demonstration, formed a relatively consistent view, that is "sub-loan crisis is essentially a credit risk from the cumulative lead to a credit crisis, but then developed capital markets led to a variety of asset prices generally fall in asset prices caused by the crisis."(Zhang Ming, 2008) However, poking the fog of superb financial operations of the Wall Street financial speculator, we can be sure to find: uncontrolled innovative financial instruments and the resulting credit risk is only triggered this "once-in" sub-loan crisis. The direct cause of the root causes is not an end. America's long-pursued by the neo-liberal economic and market fundamentalism, and the resulting "U.S.A hegemony", is the main reason.

In today's global competition pattern, China and other developing countries had no money, nor technology, nor business 
management experience. To achieve economic development, only through the active introduction of foreign investors, while the development of export-oriented economy in exchange for the necessary foreign exchange. In the "U.S. hegemony" led the world's financial system, these hard-earned foreign exchange can not be used to continue to develop the domestic economy, they are compelled to buy a large number of U.S. dollar assets such as U.S. bonds, for the United States to provide economic development debt financing, there has been "poor subsidizing the rich creditors," the strange phenomenon. This will definitely lead to China and other developing countries into the domestic shortage of public facilities, education, medical care, such as the lack of social security investment, the quality of our people can not be effectively improved, thus the division of labor in the global industrial chain to be firmly nailed to the added value of the minimum, waste of resources and environmental damage manufacturing the most serious of this aspect, while others can produce the most valuable surplus up to six components: product design, raw material procurement, Logistics and transport, order processing, wholesale operations, Retail terminal in the hands of Europe, mainly the United States. It is precisely because of the tragedy that industrial chain positioning in the end, China and other developing countries is extremely low wage level of workers, the average wages of U.S. workers less than 1 / 30 .

Nature of capital is chasing high profits. Sino-US countries such as the existence of huge wage differentials have attracted a lot of capital into China and other developing countries, and as a result of China's political stability, at all levels of government also issued a series of preferential measures to attract foreign investment, China has become the world's most suitable for foreign investment in developing countries. In the global wage arbitrage and preferential policies driven by the majority of these foreign investment flowing into the export enterprises, control more than half of China's exports, in snatched the high profits, it also brought a large number of China's foreign currency reserves. These foreign currency flows back to the United States again for the U.S. consumer-based economy provides a huge source of debt capital.

A large number of inexpensive Chinese-made goods were exported to the United States, on the one hand, the United States to reduce the prices of consumer goods, making a majority of Americans to reduce the cost of living, the middle class to enjoy the high quality of life; but on the other hand, massive transfer of capital has not driven the transfer of labor. This allows the United States, the shrinking manufacturing sector, a large number of manufacturing workers are unemployed. Bernard - U.S. House of Representatives, Mr Saunders said: "only in the past two years, we have lost two million manufacturing jobs, which is equivalent to $10 \%$ our workforce. Wal-Mart has replaced General Motors to become the United States, a major employer to pay is a matter of subsistence wages, rather than living wage. "These unemployed people mainly affected by low levels of education, minority groups and families mainly lack of funds. And their sub-loan crisis is mainly the repayment of housing loans.

The beginning of this century, with the IT bubble burst, the U.S.A government takes the real estate as a new engine of the economic development. China and other developing countries use the huge foreign exchange reserves to buy U.S. A treasury bonds and other investment products for the Wall Street Financial speculators have provided a rich source of funds. Surplus funds inevitably lead to chase higher profits, while risks increase. Thus, in the past is impossible to obtain housing loans to low-income, low levels of education, minority groups and individuals are relatively poor credit records who received mortgage loans, subprime mortgage market flourished. Wall Street had a classic saying: as long as there is an asset to generate cash flow, it can be securitized. With the subprime mortgage securities, the Wall Street investment banks, hedge funds, insurance companies and credit rating companies and other institutions also get involved the Subordinated Debt Market. In the so-called "Wall Street financial genius" under the careful packaging, MBS, CDO and CDS complex and even Warren Buffett also can not read a large number of financial products available, and increasing the size of the issue. The continued development of the U.S. economy and China State Administration of Foreign Exchange continued to provide debt financing funds made financial products sub-price bubbles as snowballed into snowball has reached the brink of bursting. U.S.A financial markets have been sitting on a powder keg, the little mars is likely to trigger a huge disaster.

\subsection{Sub- loan crisis triggering factors}

From the above analysis we can see, wage differences between China and USA is the main reason of trade imbalance and a large number of unemployed workers in the manufacturing. The United States in order to reduce rising unemployment rate, narrowing the gap between the rich and the poor, the fundamental approach should be to increase the wages of the workers in China. To do so, China's exports will create a large number of foreign exchange from the U.S.A economy back RMB economies, although in the short term would threaten U.S.A hegemony, but in the long term, this will help raise the employment rate of the United States and income of low-income and low educational level, help the U.S.A economy healthy and stable development, China and the United States economy to achieve "win-win" situation. But the world of someone who used to lead the United States, China and the United States coupled with ideological differences, the United States always has been, wearing tinted glasses to view China ,taking China as rivals rather than partners, for a long time the "containment China "as a national policy. Under such circumstances, the United States will not allow a large human resources in China to raise the wages of the workers to challenge their economic 
advantage. Thus, the loss of people to force themselves to the appreciation of the RMB has become an inevitable choice of the error. In 1985, the United States forced Japan to sign "Plaza Accord" has basically destroyed the economy of Japan's exports, but also the U.S.A economy is in recession long-term embarrassment, and ultimately caused the U.S.A stock market collapse in 1987 of "lose-lose" tragedy again.

RMB appreciation, coupled with the Fed's continued rate increases, has greatly improved the U.S. A economy, inflation and U.S.A interest rates, deeply stung by the U.S. consumer debt-based economy. U.S.A general population, especially low-income people an increasing proportion of consumer spending, rising costs of mortgages, mortgage repayment pressures increasing, and ultimately can not afford to repay loans because the emergence of a large number of break for the phenomenon of real estate by banks as collateral Commodities recovery, which ignited the second loan crisis first fire.

U.S.A economist Paul Krugman once said: "The United States has become such a country: people make a living by selling, and people buy the money from China." This phrase describes the two facts .First, the U.S.A economy driven by real estate, and the other is the United States supported by the Chinese real estate. Due to the appreciation of the RMB, China's export economy is slowing down, exports have been greatly affected, making China the ability to buy dollar assets decreased, China has not the market for the entire Subordinated Debt inject new capital, to maintain Subordinated Debt cash flow chain fracture, in the final sub-loan crisis will inevitably have taken place

\section{Sub -loan crisis on China's influence}

\subsection{Direct impact}

Due to China's regulatory authorities outside of financial institutions engaged in credit derivatives has always been more stringent controls, although some domestic financial institutions had bought some part of Subordinated Debt products, but the amount of investment accounted for a small proportion of total assets, not the company have a significant impact on overall operations, investment losses in the tolerable limits.

\section{Insert Table 1 here}

From the table I we can see that the Chinese-funded banking institutions held by Lehman Brothers and the "two rooms" related assets to total assets ratio is not great, the highest total proportion of the Bank of China also, however only 1.71 $\%$, for banks in general the impact of operational risks is not serious. In addition to the official foreign exchange reserves is concentrated in the form of holding the "two rooms" bonds over 3000 billion U.S.A dollars, in the United States Government announced the takeover of the "two rooms", the payment risks have also greatly reduced.

\subsection{Indirect impact}

Because of sub-loan crisis, the U.S.A consumer market flagging (Reuters / University of Michigan in mid-October consumer confidence index to 57.5 preliminary data, and in September compared to the same period dropped by 12.8 points in the history of the consumer confidence index drop reached or exceeded 10 points in the case, there were only 4 times.), on China's demand for imports of goods compared to the same period in previous years have come down to varying degrees. According to the General Administration of Customs statistics show that the January to August this year, Sino-US bilateral trade total value of 219.7 billion U.S.A dollars, an increase of 13.3 percent over the same period last year dropped 3.1 percentage points. In Guangdong, exports to the United States weakening trend more evident, Guangzhou Customs statistics report, January to July this year, Guangdong's exports to the U.S.A by 6.3 percent year-on-year growth rate than the same period last year dropped 7.5 percentage points, of which, clothing and clothing accessories, plastic products and toys exports registered a negative growth, exports were down 25.1 percent year-on-year, $12.4 \%$ and $4 \%$. China's coastal regions of the large number of export enterprises are facing a difficult or even bankruptcy, many companies moved to more countries and regions and with low human capital such as Vietnam. According to the National Bureau of Statistics October 9, 2008 released data show that the third quarter of the national business climate index the same period last year, were down more than Central. Export enterprises gathered in the eastern part of the climate index fell the most serious. The eastern, central and western region business climate index 128.1,131.7 and 126.8, respectively, than the second quarter and 5.5 points down 11.7,6.0; with a year earlier than eased between the range of 10-20 points. In addition, by the impact of domestic inflation, since 2007, China has been using a tight monetary policy, bank interest rates and deposit reserve rate rising, it also makes the plight of the export rise in the cost of corporate finance, financing more and more difficult, business difficult. Complex economic situation and unfavorable international economic environment, our country's monetary policy is currently facing a hard choice, the slightest mistake, it is possible to achieve economic "hard landing."

\section{Our response on sub- loan crisis}

\subsection{Adjustment "in real estate finance" policy}

The direct cause of sub- loan crisis is the base of loan products - the United States real estate market bursting of the bubble, and China's real estate bubble compared favorably with the United States. Although our country has not 
produced the soil of sub- loan crisis, but real estate prices have remained high over long-term affordability of ordinary consumers (Table II can be seen from Beijing's housing prices up 18.7 income, that is a 3 of home in the absence of any other consumer spending, the need for 18.7 years to buy a 100 square meters of housing), the real estate market will be detrimental to the healthy and stable development and the stability of financial markets and the possibility of making greater financial risk. By the end of 2007 on "real estate agent or bank first to die " controversy, as well as in some cities early in 2008 after another break for emerging phenomenon indicates that China's financial market stability and the situation is not optimistic. Urgent need is to strictly control the over-inflated real estate prices in line with economic development and the purchasing power of consumers to match with the monitoring capabilities, to develop affordable housing and low-cost housing construction, establishment and perfection of the real estate market information systems. At the same time also need to avoid big ups and downs of real estate prices, real estate adjustments should persist in being "steady" in giving priority to guard against a variety of adverse factors caused the market Superposition overshooting.

\section{Insert Table 1 here}

\subsection{The development of Waste Management is the prerequisite for the policy of expanding domestic demand}

China is a current over-dependence on foreign trade country. In 2005, China's per capita GDP for 1231 U.S.A dollars, but the per capita foreign trade volume reached 1000 U.S.A dollars, minus the part of foreign trade, and the per capita GDP was only 231 U.S.A dollars, or 63 cents a day, and the world poverty line is 2 U.S.A dollars a day. That is to say, if there is no foreign trade, China will enter the ranks of poor countries. U.S.A-led hegemony in the international financial system, earned the huge foreign exchange at the cost of wasting resources, damaging environment, reducing the real income of workers and quality of life for the U.S.A economy provided the debt financing. "China relies on exports, economic growth policies are causing growing and serious social and political factors of instability" (Liao Light, 2006). After China's reform and opening "Only GDP theory" increasingly obvious shortcomings revealed out of the growing gap between rich and poor, environmental deterioration, moral indifference growing, more and more serious corruption among officials. 2005 China's Gini coefficient has reached 0.45 , while the international warning line is 0.4 , more than 0.4 , will lead to social instability, economic inefficiency.

China has completed after 30 years of primitive accumulation, and now reached the crossroads of transition to choose the path of what kind of transition, not only determines the future development of China also decides to a considerable extent, the United States and even the direction of the global economy. Dependent on foreign trade in the traditional export-led economic growth model has drawbacks when doing now to expand domestic demand will become an inevitable choice for China. However, the lack of a complete medical education to let people come up with the protection of bank savings and more of this not to the consumer is very difficult. Future uncertain let more people keep bank life insurance money, rather than a lot of consumption, revitalizing the economy. Therefore, the key to expanding domestic demand is the stimulation of low-income people, especially farmers consumer demand. Stimulate consumer demand is an important measure for improving the social security system, reforming pensions and health care system, reducing the cost of education for pupils and students, large-scale farming subsidies to farmers to increase infrastructure investment. Realize human-based, implementing the scientific development concept. The purpose of economic development is to increase revenue, improve the quality of life, rather than to pay cuts, relying on low labor costs do for others are awake. China is currently along this goal, the Third Plenary Session of the CPC 17 clear that China must "adopt flexible and prudent macroeconomic policies, strive to expand domestic demand, especially consumer demand," Prior to this in our country have also abolished the agricultural tax, relief of the primary and secondary school tuition fees, an increase of farmers farming subsidies, reform of the medical system have begun to move forward in groping. Believe that China will certainly be able to calmly deal with the financial crisis sweeping through the world, seize the opportunity to achieve economic restructuring, keep the economy healthy and stable development.

\section{References}

It is a Wonderful Mess. (2007). The Economist, Oct.13th.

Lang, Xianping. (2008). He jumped off the industrial chain of the worst location. China Logistics and Purchasing, (3).

Li, Jun \& Wang, Li. (2008). U.S. A loan crisis meeting on the impact of China's exports and coping strategies . International Trade, (8).

Liao light. Financial war. (2008). Linxiaofang, Cha junhong translation. Beijing: Central Press.

Zhang, Ming. (2008). " U.S. A Sub-loan crisis and China" Symposium on. International Economic Review, (3).

Zhang, Ming. (2008). On the second loan crisis on the international financial system, the international situation and China's economic impact . International Economic Review, (2).

Zheng, Binxi. (2007). Perspective of the U.S. A sub-loan crisis and the Enlightenment to China. Economic and Management Research, (11). 
Table 1. As of 2008 June 30 Chinese-funded bank Lehman Brothers and the "two rooms" related assets overview

\begin{tabular}{|c|c|c|c|c|}
\hline & \multicolumn{2}{|c|}{$\begin{array}{c}\text { Related assets held by Lehman } \\
\text { Brothers }\end{array}$} & \multicolumn{2}{c|}{ Holders of the "two rooms" bonds } \\
\hline & $\begin{array}{c}\text { The total amount } \\
\text { (100 million } \\
\text { U.S.A dollars) }\end{array}$ & $\begin{array}{c}\text { The proportion of } \\
\text { total assets }\end{array}$ & $\begin{array}{c}\text { The total amount } \\
\text { (100 million } \\
\text { U.S.A dollars) }\end{array}$ & $\begin{array}{c}\text { The proportion of } \\
\text { total assets }\end{array}$ \\
\hline $\begin{array}{c}\text { Bank of China } \\
\text { Commercial Bank } \\
\text { of China }\end{array}$ & 1.2882 & $0.01 \%$ & 172.86 & $0.15 \%$ \\
\hline $\begin{array}{c}\text { Construction Bank } \\
\text { China Merchants } \\
\text { Bank }\end{array}$ & 1.516 & $0.01 \%$ & 27.16 & $0.32 \%$ \\
\hline $\begin{array}{c}\text { China CITIC } \\
\text { Bank }\end{array}$ & 0.7 & $0.019 \%$ & 2.55 & $0.13 \%$ \\
\hline $\begin{array}{c}\text { Bank of } \\
\text { Communications }\end{array}$ & 0.7 & $0.03 \%$ & 15.84 & $0.9 \%$ \\
\hline
\end{tabular}

Table 2. 2007 house prices in major cities of China's income table

\begin{tabular}{|c|c|c|c|c|c|}
\hline City & $\begin{array}{c}\text { Capita } \\
\text { disposable } \\
\text { income(yuan) }\end{array}$ & $\begin{array}{c}\text { The average selling } \\
\text { price of } \\
\text { commercial } \\
\text { housing (yuan / sq } \\
\text { m) }\end{array}$ & $\begin{array}{c}\text { Household } \\
\text { disposable } \\
\text { income (at 3.1 } \\
\text { per household } \\
\text { basis) }\end{array}$ & $\begin{array}{c}\text { Price of } \\
\text { commercial } \\
\text { housing units } \\
\text { (100 square } \\
\text { meters each) }\end{array}$ & $\begin{array}{c}\text { Rates } \\
\text { revenue }\end{array}$ \\
\hline Beijing & 19978 & 11553 & 61931.8 & 1155300 & 18.7 \\
\hline Shanghai & 23623 & 8361 & 73231.3 & 836100 & 11.4 \\
\hline Tianjin & 16357 & 5794 & 50706.7 & 579400 & 11.4 \\
\hline Wuhan & 14358 & 4664 & 44509.8 & 466400 & 10.5 \\
\hline Chongqing & 12591 & 3385 & 39032.1 & 338500 & 8.8 \\
\hline Nanjing & 19600 & 5304 & 60760 & 530400 & 8.7 \\
\hline Nanjing & 21689 & 11054 & 67235.9 & 1105400 & 16.4 \\
\hline Guangzhou & 22469 & 7993 & 69653.9 & 799300 & 11.5 \\
\hline Shenzhen & 24870 & 13376 & 77097 & 1337600 & 17.3 \\
\hline Average & 19503.9 & 7942.7 & 60462.1 & 794270 & 13.1 \\
\hline
\end{tabular}

Date Sources: National Bureau of Statistics, the real estate industry development research report in China and major cities, 2008. 